\title{
Differential Impacts of Wind Energy on Sustainable Power Generation in Ghana
}

\author{
Jones Lewis Arthur ${ }^{1}$, Patrick Adu-Wiafe ${ }^{2}$ \\ ${ }^{1}$ Department of General Agriculture, Sunyani Technical University, Sunyani, Ghana \\ ${ }^{2}$ Department of Mechanical Engineering, Kwame Nkrumah University of Science and Technology, Kumasi, Ghana \\ Email: jonesarthur2002@gmail.com,patrickwiafe54@yahoo.com
}

How to cite this paper: Arthur, J.L. and Adu-Wiafe, P. (2020) Differential Impacts of Wind Energy on Sustainable Power Generation in Ghana. Journal of Power and Energy Engineering, 8, 84-103.

https://doi.org/10.4236/jpee.2020.810007

Received: October 4, 2020

Accepted: October 27, 2020

Published: October 30, 2020

Copyright $\odot 2020$ by author(s) and Scientific Research Publishing Inc. This work is licensed under the Creative Commons Attribution International License (CC BY 4.0).

http://creativecommons.org/licenses/by/4.0/

\begin{abstract}
Ghana has a yearly development interest for power at a rate of $83.8 \%$ in 2010 , and to $12 \%$ from 2020 to 2040 but this opportunity has been farfetched with the shocks in energy generation during 1983, 1994, 1997-98, and 2006-2007 era pushing the energy sector into crisis and a consequent adverse impact of $1.5 \%$ to GDP. This study, therefore, investigated the differential impacts of wind energy to sustainable power generation in Ghana by assessing the determinants of energy supply, energy demand and supply mix for energy development, the capacity of the energy sector to develop wind power and possible challenges in developing wind power energy in Ghana. An exploratory design that adopted both qualitative and quantities approaches was applied to the study. The study population involving 34 sample sizes was accessed from a 46 population made up of management/ministers of energy and counsellors or energy experts. The study concluded that the demand for energy in Ghana has increased over the years but without a commensurate increase in energy supply. Major reasons for the shortfall in energy supply have centred on the monopoly enjoyed by the major power producer which invariably places stress on its ability to supply energy to meet the increasing demand. It also came out that wind energy has the potential to contribute to the overall energy fortunes of Ghana. However, a focus on wind energy may not produce the required results of reducing the energy supply gap due to a preference for solar and natural gas oils. It was also noteworthy that the need to build capacity to develop and maintain wind energy through critical, current infrastructure stance of the Ghanaian energy sector would not make this agenda of developing wind energy a reality. More so, it is important to note that the need to enhance the current weak national policy, financial backing and bridge technology gap for wind energy would be needful to realise a vibrant investment into wind energy development.
\end{abstract}




\section{Keywords}

Wind Energy, Supply and Demand, Technology, Capacity Building, Energy Policy

\section{Introduction}

The dynamics in access and costs of key advances in sustainable power sources has resulted in the increasing importance of energy as an essential resource, the worldwide move of Chinas economy as a subsidiary of the strict development from the utilization of coal and the pervasive mastery of the oil and gas generation by America [1].

Generally, Africa lags behind the world in this energy assorted variety [1] [2]. It has been approximated that almost 620 million people live with no access to an electrical supply and a challenging estimation of more than 730 million use hazardous and unsafe strategies for cooking which adversely influences their livelihoods [3]. Even so, people who have relevant access to power are troubled with the associated high costs. The need to increase access to energy is critical for the many areas on the Africa continent where there is no capacity to meet energy requests of its kind [4].

Ghana a developing country in Sub-Saharan Africa is confronted with an emergency-engineered approach to building the energy capacity due to an overhyped bureaucratic because of poor regulatory structures to administer the segment [5]. The transformation of the energy business since 1980 has turned into the pathway of an inconclusive power battle. Ghana's power access is approximated $72 \%$ with over $87 \%$ for the urban areas and towns and about a substantial energy supply locked in trade with the neighbouring nations [1]. Consequently, interest for energy continues cresting at a request rate of $10 \%$ every year thus calling for the need to search for other maintainable energy sources. These developments have called into action, the need to explore other alternative sources of energy, including biomass, solar and wind, and on a lesser note the small scale hydropower framework.

Ghana has a yearly development interest for power at a rate of $83.8 \%$ in 2010 , and to $12 \%$ from 2020 to 2040 [6] [7]. However, this opportunity has been farfetched with the shocks in energy generation during 1983, 1994, 1997-98, and 2006-2007 era pushing the energy sector into crisis and a consequent adverse impact of $1.5 \%$ to GDP [8] [9]. A single phased energy generation that is hydropower has not been effective in addressing the energy challenges as thermal power was introduced along the way [10]. The crises in the sector including dwindling yields from hydropower and the high cost of thermal energy made the call for also alternative and viable energy sources such as wind energy to become prominent and promising [11].

Some scholars have argued that developing wind energy comes with a higher 
initial cost but also has the potential to generate a higher amount of energy that can outweigh the capital contributed to generating it [12]. As part of the development in the wind energy sector, Ghana has built up the Sustainable Energy for All Action Plan, which is tied to the Renewable Energy Act promulgated by the Parliament of Ghana in 2011 [9]. The Plan seeks to incorporate the arrangement for improvement, administration, usage, manageability and satisfactory supply of sustainable power sources. The drive to wind energy was heightened by collaborative on-and seaward appraisals by United Nations Environment Program (UNEP), the US National Renewable Energy Laboratory (NREL) and the Ghana Meteorological Service to that identified that Ghana has a breeze control potential [6] [13].

The report of the Solar and Wind Energy Resource Assessment (SWERA) investigation carried out between 2002-2005 concluded that; of the 6 Wind classes, (with Class 6 being the most noteworthy breeze asset potential and Class 1 being the least), Ghana has Class $4-6$ wind assets at the most noteworthy edges close to the fringe with Togo and the most astounding edges northwest of Accra [13]. More so, there is roughly $413 \mathrm{~km}$ square territory with great to-magnificent (Class 4 - 6) wind asset which could bolster a little more than $2000 \mathrm{MW}$ of wind control, and if direct to amazing breeze assets is incorporated, that could go up to $5640 \mathrm{MW}$ [6] [14]. Notwithstanding these, strengths and opportunities, the government of Ghana has not been able to utilize the options due to inadequate specialized professionals coupled with the lack of political will to develop and tap wind energy resource [15] [16]. These weaknesses among others are the motivation to undertake this study that investigates the differential impacts of wind energy to sustainable power generation in Ghana. Key objectives that the study explored include;

- Assess the determinants of energy supply in Ghana.

- Examine energy demand and supply mix for energy development in Ghana.

- Explore the capacity of the energy sector to develop wind power energy in Ghana.

- Identify the possible challenges in developing wind power energy in Ghana.

\section{Literature Review}

\section{Energy Demand and Supply Matrix}

Energy development worldwide has transited through many phases. These phases cut across the last hundred years specialized advancement which has enhanced the global capacity to explore and access many non-renewable energy sources [17]. Amid the growth in energy exploration in the mid-eighteenth-century was the creation of a steam motor in England and later to the development of James Watt's effective motor [18]. Later transitions in energy development led to the utilization of coal in locomotive engines, boats and metallurgy.

Oil marketing is known to have taken place in 1859 by Colonel Edwin Drake in Titusville Pennsylvania [19]. Initial production which stood at only 15 barrels 
of oil multi-day, later in that year catapulted to 500.000 barrels for every day, and after two years to three million barrels for each day. The initial use for oil was to create fuel lamp for lighting but these changes in 1882 to mainly power age plants to be fabricated [18]. The rising energy demand cultivated into up-scaling of petroleum derivative generation, and the presentation of new extraction strategies; actions that led to a reduction in the cost of energy as a result of the increased demand for oil and associated products [17]. The specialized advancement in oil-related activities including demands led to the diversity in energy options including calls for exploration and exploitation in renewable forms of energy.

Many developments have taken place in world energy markets and ventures since 2002 such that, business is persuaded to consider energy issues as critical to the survival of a business. For example, the costs of energy have increased for many countries; the demand of oil has increased by $125 \%$; costs of coal import to Japan by $100 \%$, petroleum gas in North America by $200 \%$ and in Europe, by $100 \%$ [20]. But, the supply of energy to meet demand relies heavily on regulatory controls and how effortlessly such powers can be conveyed [9]. Therefore, the key determinant of energy demand has been argued to be the outfitting of the populace and monetary development for lighting, warming, cooling and versatility; this couplet constitutes the motor of the energy economy. The increasing energy demand has searched for and use alternatives forms of energy such as the renewable a necessity and hallmark for the survival of communities.

\section{Wind Energy as Alternative to Energy Generation}

Wind energy has become popular energy worldwide, due to its clean characterises and the fact that it prevails virtually everywhere in the world [21]. It has been projected that the current global installed capacity of wind power generation may increase from the current generation of 540 (2017) to $5800 \mathrm{GW}$ by 2050 [22]. However, for effectiveness, any promising alternative energy should such as wind be harvested in a promising manner even in places of low wind potential, if a careful assessment of the resources such as the exact point to install a wind turbine is conducted. One of the remarkable attributes in the breeze control age is its vulnerability because of the sudden change in both breeze speed and bearing, particularly for off-matrix wind control age frameworks [23] [24]. Identifying and incorporating the most effective framework for developing wind energy continue to attract much scholarly discourse.

Several frameworks have been proposed to harness and harvest wind energy for sustainable energy generation. These models include the Wind-Sun Powered Crossover Framework that incorporates the complementary roles of sunlight and wind-generated energy systems [8] [25] [26] [27]. The utilization of wind-sun based cross breed frameworks extends broadly from private houses to civil and mechanical offices, either lattice associated or independent. The Wind-hydro half breed framework which correlates wind breeze control circulation that draws on the comparative advantages of wind and hydropower with a particular look at the various comparative diverse opportunities and challenges accruable to each 
mode at the different seasons of the year [28] [29] [30]. Other options for integrating wind energy into sustainable energy systems are the wind-hydrogen framework where breeze control, sun based power and other sustainable power source control age frameworks could be coordinated with the electrolysis hydrogen creation framework to deliver hydrogen fuel [31], and wind-diesel control age framework where wind power could be joined with control delivered by diesel motor generator frameworks to give a steady supply of power [32].

\section{Challenges Associated with the Development of Wind Energy}

Although they have been arguments for active development in wind energy, the sector continues to see few developments due to key challenges that grapple efforts to incorporate wind in energy development systems. Although the development of wind energy provides clean alternative energy, the process has challenges including those related to market maturation, the challenges associated with increasing share, energy storage, motivational conflicts, demand responses and optimal scheduling emerge and are expected to be resolved [33].

Other arguments against the development of wing energy relate to the size dimensions. For example, the developments of large wind turbines depend on several components that come with related challenges rather than just one. The key challenge is a matter of social acceptance, the logistics of transport and erection, and issues of the medium-term sustainability of the political and economic support for wind energy [34]. The potential aerodynamic noise and the allowed distance from the turbine could pose a major challenge to wind energy development. Other literature has cited obstacles include policy, institutional, regulatory, financial, and information and technological barriers [35] [36].

But for developing countries including Ghana issues of lack of public awareness and technological knowledge, the complex nature of administrative procedures, weak and obsolete electricity transmission lines and the difficulty to attract workers qualified in the field of renewable energy continue to pose key challenges to wind energy development [36]. [37] also identified several challenges for operation and maintenance of the offshore wind energy sector. These challenges were categorized under four themes relating to issues related to industry immatureness, distance/water depth, weather window, and policy issues. These challenges present an important foundation to assess Ghana's whether the development of wind energy can impact on sustainable energy generation in Ghana.

\section{Materials and Methods}

The study took into cognizance the exploratory research design and with a focus on assessing whether wing controlled energy can support sustainable energy development in Ghana. Population which portrays the aggregate subject of a gathering, society, or network [38] consisted of 52 staff of selected energy-based institutions; the Ministry of Energy (Minster and arrangement counsellors) and Energy Commission of Ghana (Management and Policy consultants). The sample size was accessed from the use of [39] formulae for establishing sample size. 


$$
S=\frac{X^{2} N P(1-P)}{d^{2}(N-1)+X^{2} P(1-P)}
$$

$S=$ Required sample size;

$X=\mathrm{Z}$ value (e.g. 1.96 for $95 \%$ confidence level);

$N=$ Population size;

$P=$ Population proportion (expressed as decimal) (assumed to be 0.5 (50\%);

$d=$ Degree of accuracy (5\%), expressed as a proportion (0.05). It is a margin of error.

A sample size of 46 was, therefore, derived for the study. The sample was grouped into 12 for Management/Ministers and 34 approach counsellors or experts. The sort of testing framework used would choose the examining size that can be gained. [40] perceives probability and non-probability examining strategy.

The investigation used probability testing technique to allow for a fair chance for the inclusion of respondents. A cluster has applied to group the respondents into Management/Ministers and Counsellors/Experts in energy development. The simple random sampling approach (lottery) was used to select the respondents from each cluster of the population. This approach was helping in providing an equal chance for all respondents and, therefore, was instrumental in reducing bias in the choice of respondents [40].

Data collected for the research were in two (2) folds; secondary data was accessed through books and journal articles whereas questionnaires were used to collect primary data. Questionnaires were organized into four principal segments; section A on demographics of respondents, section B related to the demand and supply of wind control energy in Ghana, second C output of energy in Ghana and section $\mathrm{D}$ on the difficulties in creating wind control energy in Ghana. The five-point Likert scale was utilized for reactions. The range was from strongly agree, agree, uncertain, disagree and strongly disagree.

A pre-test and actual administration was conducted during the $8.00-5.00 \mathrm{pm}$ working hours to ascertain whether questions were representative to the population. After the data gathering utilizing overviews, each arrangement of inquiries was numbered. The arrangement of inquiries was numbered from 1 to 27 with the goal that each study would have an exceptional number. The data on each study information were re-organized with Microsoft Excel. The re-organized data in Excel would then be exported to Statistical Product for System Solutions (SPSS) Statistics Version 16.0 to facilitate the analyses by the use of tables, frequencies, mean, and percentages.

Ethical considerations were given priority attention to allow for fairness in the choice to respondent to the questions. Especially issues of confidentiality, voluntary participation, and knowledge of the purpose of the study were communicated to respondents.

Efforts were made to ensure the reliability and validity of data. Errors of measurement that affect reliability are random errors and errors of measurement 
that affect validity are systematic or constant errors. To ensure the reliability of the data collected, the research ensured that the respondents answered the questions with an understanding of the questions as well as ensured that respondents attended to questions at the most convenient period. To ensure the validity of the data, extant literature was consulted before developing the questionnaire as well as the conduct of a pilot study to test the strength of the questions.

\section{Results and Discussions}

The analysis and discussions are grouped under the demographics and issues relating to the differential impacts of wind energy to sustainable power generation in Ghana. The questions were also analyzed using the Relative Importance Index (RII) and Mean score rankings. Other analysis such as Cronbach's Alpha coefficient test assessed the reliability of the data. An acceptable response rate of $74 \%$ [41] that is, 34 out of 46 administered questionnaires was retrieved.

\section{Demographics of Respondents}

In the study (Table 1), the majority (64.7\%) of the respondents were males, whereas $35.3 \%$ were females. This trend did not impact the integrity of the results since respondents were accessed based on their in-depth knowledge of the issues being investigated. The majority (52.9\%) of the respondents fell under the age range of $31-40$ years. The others were $35.5 \%$ for $21-30$ years and $11.8 \%$ for 41 - 60 years. The resultant data confirms a youthful population for respondents in the two ministries. In all 5.9\% of the respondents came from Senior/Management level, $70.6 \%$ from middle level whilst $23.5 \%$ came from lower management. The results, therefore, suggest that approximately $76.5 \%$ of the respondents in the survey have some level of in-depth knowledge about energy and for that matter wind energy.

\section{Determinants of Energy Supply in Ghana}

Table 1. Demographic background of respondents.

\begin{tabular}{ccc}
\hline & Frequency & Percent \\
\hline Sex & 22 & 64.7 \\
Male & 12 & 35.3 \\
Female & & \\
Age & 12 & 35.3 \\
$20-30$ yrs & 18 & 52.9 \\
$30-40$ yrs & 4 & 11.8 \\
$41-50$ yrs & & \\
Position in Employment & 2 & 5.9 \\
Senior/Management Level & 24 & 70.6 \\
Middle level & 8 & 23.5 \\
Junior Level & &
\end{tabular}

Source: Fieldwork, 2018. 
This question explored whether Ghana can meet the current energy demand. All respondents agreed to the fact that Ghana cannot meet the energy needs requirement of the nation. The results show a general weakness in the energy sector because the sector is unable to produce to meet the energy needs of consumers within the country. The need to explore alternative options for generating energy is critical to meeting the energy demands for a developing country such as Ghana.

On the cost of the current individual energy supply for individual consumers, it became clear that $88.2 \%$ were in agreement that it has changed/increased but, $11.8 \%$ differed in their view. This development suggests a general increase in the energy demand of individual consumers. It is, however, disturbing to acknowledge that the country has been unable to increase energy supply to meet the increasing energy demand. This definitely is a recipe for shortage in the energy market.

Major Factors That Affect the Demand and Supply Chain of Energy in Ghana

Respondents were asked to rank on the 5-point Likert scale, the extent to which respondents agree to the following as the major drivers of the demand and supply chain of energy in Ghana. The Likert scale ranged from 1 - 5 as follows: 1 -Strongly agree, 2-Agree, 3-Uncertain/undecided, 4-Disagree and 5-Strongly disagree. The underlying conditions for the analysis included a $95 \%$ confidence interval, this is, based on the five-point Likert scale rating where two or more criteria have the same mean and the one with the lowest standard deviation assigned the highest significance ranking [42]. According to [42], the standard error is the standard deviation of sample means as well as a measure of how likely a sample represents the population. Hence, a large standard error (relative to the sample mean) suggests that there is a lot of variability between means of different samples. On the other hand, a small standard error suggests that most sample means are similar to the population mean; therefore, the sample is likely to be an accurate reflection of the population. The standard error associated with all the means is relatively close to zero suggesting that the sample chosen is an accurate reflection of the population.

Scores for factors that affect the demand and supply of energy registered highest $($ mean $=3.59$, S.D. $=0.507$ ) for the monopoly of a supply source and agency and lowest $($ mean $=2.93$, S.D. $=0.807)$ for the presence of alternative sources of energy (Table 2).

The results show that the major factor which adversely impacts the supply of energy is the sole control of energy supply, that is, the Electricity Company of Ghana (ECG) (Table 2). It is important to also note that the existence of alternative fuel sources would not necessarily be a key factor in the determination of the demand and supply mix for energy. The development of alternative energy sources, though ambitious in its relevance, would not necessarily help in resolving demand and supply inefficiencies in energy development. 
Table 2. Factors that affect the demand and supply chain of energy.

\begin{tabular}{lccc}
\hline & Mean & S.D. & Ranking \\
\hline The monopoly of a supply source and agency & 3.59 & 0.507 & 1 st \\
Low level of technological advancement & 3.41 & 0.516 & 2 nd \\
Old and non-renewed policy demands of the energy sector & 2.93 & 0.807 & 3 rd \\
Presence of alternative fuel sources & 2.53 & 1.007 & 4 th \\
\hline
\end{tabular}

Source; Field Work, 2018.

On the level of satisfaction with the output of the energy sector of Ghana, a 5-point Likert scale ranging between 1-Very satisfied, 2-Satisfied 3-Uncertain, 4-Less satisfied, 5-Not satisfied were used in the assessment. It came out of the study that $64.7 \%$ were less satisfied and with 35.3 indicating a not satisfying response (Table 3). The performance of the energy sector fell below the expectations of the general populace.

This development, therefore, challenges the energy sector to intensify or modify their method of production so that they can enhance their output to meet the expectation of the general public. An assessment of whether the development of wind energy can meet the energy demand of its customers was conducted. It came out that there was a majority (mean $=3.9$, S.D. $=1.121)$ support in the capacity of wind energy to help meet the energy demands of only parts of the country (Table 4). The argument on the inability to use wind energy to meet the energy demand (mean $=2.51$, S.D. $=1.047$ ) had marginal support.

It is, therefore, appropriate to imply that respondents are more convinced that wind energy can only meet some fraction of energy demand for the national populace. However, the capability or possibility of wind energy to meet the demands of energy consumers in the entire nation was rank least (4th) with a mean of 2.51. It, therefore, suggests that respondents are not convinced of the ability or the possibility of wind energy to serve the whole country. One of the notable characteristics in the wind power generation is its uncertainty due to the sudden change in both wind speed and direction [23]. Therefore, the power output from wind turbines fluctuates from time to time. For this purpose, it is beneficial to integrate wind and other complementary energy sources to form hybrid power systems for assuring the stability and reliability of power supply and reducing the requirement for the wind energy storage [43].

\section{Potential of the Current development in Wind Energy}

The perception of respondents on whether current developments in wind energy have the potential to address the shortfall in energy is shown in Table 5. The highest-ranking perception was that the potential of wind energy to address the energy shortfall was failing. But on whether the current development in wind energy has been highly successful was rated by respondents as lowest.

Generally, the results indicate that respondents strongly believe that the current development in the wind energy sector is falling and that it has minimal hope of being successful. This suggests that the Ghanaian energy sector has not 
Table 3. Extent you are satisfied with the output of the energy sector in Ghana.

\begin{tabular}{ccc}
\hline & Frequency & Per cent \\
\hline Less satisfied & 22 & 64.7 \\
Not satisfied & 12 & 35.3 \\
Total & 34 & 100.0 \\
\hline
\end{tabular}

Source: Field survey, 2018.

Table 4. The capability of wind energy to meet demand.

\begin{tabular}{lcccc}
\hline & Mean & S.D. & Ranking \\
\hline It can meet the energy demands of only some parts of the country. & 3.91 & 1.121 & 1 st \\
It is impossible to tell whether it can meet or not. & 3.53 & 1.068 & 2nd \\
It is capable of meeting the energy demands of the entire nation. & 3.24 & 1.091 & 3rd \\
It is incapable of meeting the energy demands of the country. & 2.51 & 1.047 & 4th \\
\hline
\end{tabular}

Source: Field survey, 2018.

Table 5. Perception of the potential of the current development in wind energy.

\begin{tabular}{cccc}
\hline & Mean & S.D. & Ranking \\
\hline It is gradually failing & 3.47 & 0.943 & 1 st \\
It has already failed & 3.41 & 0.870 & 2nd \\
It is beginning to succeed & 1.88 & 0.600 & 3 rd \\
It has been highly successful & 1.82 & 0.636 & 4 th \\
\hline
\end{tabular}

Source: Field survey, 2018.

realized much significant progress in wind energy development and production to meet energy demand.

The Readiness of Ghanaian Society for a Change in Source of Energy Usage

Another variable used to measure how satisfactory consumer is relative to the output of the energy sector was the readiness of Ghanaian society for a change in the source of energy usage. Thus, the study sought to assess the readiness of consumers for a change in the consumption pattern (source of production) of energy. This variable will help us to know the degree at which the Ghanaian society is ready for a change in the source of energy production and usage, mainly from hydro energy to wind energy. The question was useful as it enabled the researcher to assess the readiness of consumers to accept other sources of energy for consumption, that is, wind energy (Table 6).

It came out that $47.1 \%$ of the respondents are of the view that Ghanaians are ready for a change in the source and usage of energy usage whereas the majority (52.9\%) suggested otherwise. This suggests that the energy sector of Ghana thinks that the consumers will need time to embrace any new form of energy, mainly wind energy. This development will dampen the zeal of the sector to undertake 
Table 6. Readiness of Ghanaian society to embrace a change in energy source and usage.

\begin{tabular}{ccc}
\hline & Frequency & Per cent \\
\hline Yes & 16 & 47.1 \\
No & 18 & 52.9 \\
Total & 34 & 100.0 \\
\hline
\end{tabular}

Source: Field survey, 2018.

any strategic decisions and development to revamp the wind energy sector. A lot more sensitization effort would be needed to change this mindset to develop and introduce other forms of energy such as wind energy.

\section{Preference for Energy Sources}

On a scale of 1 - 5 with 5 as highly preferred, 4-Preferred, 3-Uncertain, 2-Less preferred, 1-Not preferred, the respondents were asked to identify their preference for energy sources by ticking the appropriate value. The best energy preference for the energy experts sampled as respondents are solar energy (mean $=4.47, \mathrm{~S} . \mathrm{D} .=0.514)$. It can therefore be inferred that solar energy is highly recommended to the energy sector as an alternative source of energy. It further suggests that the degree at which respondents (the energy sector) prefer solar energy was approximately $45 \%$. As shown in Table 7 , the result further indicated that wind energy was averagely preferred with a mean score of 4.13 ahead of hydro energy which is the main source of energy in Ghana. This means that the intensity at which sector gives preference to wind energy was about $14 \%$ on the average. By implication it can be inferred that wind energy is much preferred to hydro possibly due to the cost advantage it will have over hydro energy generation. The least preferred energy options were nuclear energy (mean $=2.06$, S.D. $=1.029)$.

\section{Capacity of the Energy Sector to Develop Wind Energy in Ghana Whether the energy sector has the right technology to develop wind energy in Ghana}

Many have argued for the key roles that technology could play in every aspect of development. Therefore, for energy sector improvement in wind energy in the country would largely require the availability of modern and effective technology for the production of wind energy. It is, therefore, necessary to investigate whether the energy sector is indeed ready to enhance the production of wind energy for the country. With this hind side, the researcher explored whether the energy sector has the requisite technology to develop and enhance wind energy in Ghana (Table 8 ). In all, the majority (64.7\%) as against the minority (35.3\%) suggested that the energy sector cannot develop the requisite technology for wind energy in Ghana.

This, therefore, implies that majority of the respondents are certain that the energy sector does not have the appropriate technology to develop wind energy in Ghana. This development is indeed a deep blow to the arguments to develop and enhance appropriate wind energy to supplement other forms of energy generation and use in Ghana. 
Table 7. Energy preference.

\begin{tabular}{ccccc}
\hline & $N$ & Mean & Std. D. & Ranking \\
\hline Solar Energy & 34 & 4.47 & 0.514 & 1 st \\
Production by natural gas and oils & 34 & 4.41 & 1.121 & 2nd \\
Wind Energy & 34 & 4.13 & 0.514 & 3rd \\
Hydropower & 34 & 2.82 & 1.185 & 4 th \\
Production by coals & 34 & 2.72 & 0.951 & 5 th \\
Nuclear & 34 & 2.06 & 1.029 & 6 th \\
\hline
\end{tabular}

Source: Field survey, 2018.

Table 8. Whether the energy sector have the requisite technology to develop wind energy in Ghana.

\begin{tabular}{ccc}
\hline & Frequency & Per cent \\
\hline Yes & 12 & 35.3 \\
No & 22 & 64.7 \\
Total & 34 & 100.0 \\
\hline
\end{tabular}

Source: Field survey, 2018.

Whether current energy sector policies back the development of wind energy in Ghana

Generally, it is believed that any good development agenda should be back by good and applicable policy, something applicable to the energy sector as well. As a result of this underlying support, respondents were assessed on whether the development of wind energy in the country is supported by any good policy. Will be effective or not will depend partly on policy design for it. Given this, the respondents were asked to choose yes, no or uncertain to indicate whether they think current energy sector policies back the development of wind energy in Ghana.

Scores indicating that $17.6 \%$ of respondents suggest that there is no energy sector policy to back the development of wind energy in Ghana especially (Table 9). The result was not surprising, especially reflecting on the fact that respondents have initially indicated that the energy sector had no requisite technology to back the development of wind energy in Ghana.

Table 9 presents the responses from the respondents on ascertaining whether the current energy sector policy supports the development of wind energy. From the table, 6 of the respondents representing $17.6 \%$ of the respondents indicated that the current policies of the energy sector in Ghana support the development of wind energy. Again, 35.3 per cent of the total respondents were uncertain about whether the current energy sector policies are in support of the development of wind energy or not.

\section{Adequacy of Monetary Resources to Develop Wind Energy in Ghana}

An examination of whether there were adequate resources to back the development of wind energy was conducted (Table 10). Again, a minority (34.6\%) 
Table 9. Whether current energy sector policies back the development of wind energy in Ghana.

\begin{tabular}{ccc}
\hline & Frequency & Per cent \\
\hline Yes & 6 & 17.6 \\
No & 16 & 47.1 \\
Uncertain & 12 & 35.3 \\
Total & 34 & 100.0 \\
\hline
\end{tabular}

Source: Field survey, 2018.

agreed to the adequacy of resources for wind energy development and with the majority (58.8\%) stating the converse. The results showed that the current energy sector does not have adequate monetary resources to develop wind energy in Ghana.

Potential Challenges Associated with the Development of Wind Energy in Ghana

Several issues adversely impact energy development in Ghana's a result respondents were asked to rank some key challenges argued to impact wind energy development. Scores for means and standard deviation show that the major factor militating against the development of wind energy is lack of financial aid to assist in production (mean $=4.59$, S.D. $=0.507)$.

Meanwhile, the least impacting factor $($ mean $=3.47$, S.D. $=0.514)$ as indicated by respondents, was the issue of improper policy changes to facilitate the use and implementation of wind energy (Table 11). The main two issues (lack of financial and technological aids) are critical for the development of wind energy and its absence will be a major debilitating factor to wind energy development in Ghana.

Addressing Challenges Associated with the Development of Wind Energy in Ghana

Respondents were asked to rank a set of identified factors from the literature that provide support lessons for addressing the challenges associated with the development of wind energy. The score clearly shows financial support to aid wind energy production (mean $=3.95$, S.D. $=0.996$ ) by the government as a major catalyst to support win energy development in Ghana (Table 12).

This was followed by technological aid to assist the production of wind energy as 2 nd most critical factor (mean $=3.65$, S.D. $=0.870$ ). Change in policy to facilitate the implementation of wind energy was ranked third, with a mean of 3.05 whilst educating the public on the importance of developing wind energy in the country was ranked fourth and least impacting factor with a mean of 2.59.

\section{Discussion of Findings}

\section{Determinants of Energy Supply}

Generally, the energy demand has increased over the years but not the supply strength [20]. The impact is the worrying trend of energy shortage that culminates 
Table 10. Adequacy of monetary resources to be used to develop wind energy in Ghana.

\begin{tabular}{ccc}
\hline & Frequency & Per cent \\
\hline Yes & 8 & 23.5 \\
No & 20 & 58.8 \\
Uncertain & 6 & 17.7 \\
Total & 34 & 100.0 \\
\hline
\end{tabular}

Source: Field survey, 2018

Table 11. Potential challenges associated with the development of wind energy in Ghana.

\begin{tabular}{lccccc}
\hline & $N$ & Mean & S.D. & Ranking \\
\hline Lack of financial aid to assist in the production & 34 & 4.59 & 0.507 & 1 st \\
Lack of technological aid & 34 & 4.41 & 1.312 & 2nd \\
Non-acceptance on the part of the user community & 34 & 3.66 & 0.600 & 3 rd \\
Improper policy changes to facilitate use and implementation & 34 & 3.47 & 0.514 & 4 th
\end{tabular}

Source: Field survey, 2018.

Table 12. Addressing challenges associated with the development of wind energy in Ghana addressing challenges.

\begin{tabular}{|c|c|c|c|c|}
\hline & $N$ & Mean & Std. D. & Rankings \\
\hline $\begin{array}{l}\text { Financial support to aid wind energy production by the } \\
\text { government }\end{array}$ & 34 & 3.95 & 0.996 & 1 st \\
\hline $\begin{array}{l}\text { Appropriate technological aid to assist the production of } \\
\text { wind energy }\end{array}$ & 34 & 3.65 & 0.493 & 2nd \\
\hline Change in policy to facilitate its implementation & 34 & 3.05 & 0.728 & $3 \mathrm{rd}$ \\
\hline $\begin{array}{l}\text { Educating the public on the importance of developing } \\
\text { wind energy in the country }\end{array}$ & 34 & 2.59 & 0.870 & 4 th \\
\hline
\end{tabular}

Source: Field survey, 2018.

into a loss of energy required to undertake productive activities. The trend supports the argument of [42] that suggests that improving access to energy was critical as it has compelled many countries to continue to explore opportunities in energy sustenance. Many reasons for the supply trend are the monopoly enjoyed by the energy producer which ultimately affects innovation and involvement other energy industry players who could invest in other energy sources to lessen the demanding stress on the single energy producer.

Although the availability of other alternative sources could have meant the supply of additional energy to augment the demand shortfall, consumers continue to face shortfalls indicating that availability of these alternative sources does not necessarily translate in energy supply efficiency. Again, the shortfalls in energy supply also confirm the assertions of [9] who argued that Ghana has not been able to recover from shocks in energy generation that took place during $1983,1984,1997-1998$ and 2006-2007 But it is important to note that the need to 
increase access to energy is critical for the continent because Africa has a weak capacity to meet energy requirements [4].

The underlying trend will be a dissatisfied consumer due to inefficiencies in the output of the energy sector in Ghana. But, the question that crops many minds is whether wind energy can meet the demand shortfall. This study was rather suggestive of the fact that there is a general perception that the development of wind energy can only help in meeting the energy needs of only part of the country. Although the study adds that the development of wind energy can alleviate energy shortages for part of the country, it is still worthwhile making the effort due to the peculiar advantage the country can enjoy by developing wind energy including the availability of an amazing breeze [6] [13].

\section{Wind Energy as Alternative to Energy Generation}

Developing wind energy is important but it is also important that such a project meets the readiness of the Ghanaian economy to accept the change. With the current shortfall in energy supply, alternative energy options would be relevant in meeting the current demand for energy in Ghana [22] [44]. More so, the study suggested that majority (47.1) of the energy experts are of the view that the Ghanaian society is ready to embrace a change in energy source including wind energy to meet the increasing demand for energy in the country [45].

Notwithstanding the need for an alternative energy source, the development of wind energy is likely to encounter serious difficulty since the majority (mean $=4.47, \mathrm{~S} . \mathrm{D}=0.514$ ) have a preference for solar and natural gas oils (mean = 4.42 , S.D. $=1.121$ ). Although, wind energy as an alternative power supply which has been viewed to be economically efficient and a renewable source of energy place itself to solve the current energy quagmire in Ghana [5] [6] the general option is for wind energy.

\section{The Capacity of the Energy Sector to Develop Wind Energy in Ghana}

Although wind energy is argued by some expert to be an important energy source for many [21], the capacity to develop and maintain wind energy is critical [9]. The study hinted that the current infrastructural stance of the Ghanaian energy sector is weak and unable to accommodate the adoption of wind energy. Therefore, the adoption of appropriate technology energy-mix could be adopted by Ghana to source the complementary roles of other energy sources such as sunlight and wind energy systems [8] [26]. [9] is of the view that wind energy is a new technology that has the potential to propel development.

But, the study indicated that the energy sector does not have the requisite technology and energy sector policy to back the development of wind energy in Ghana. The study backs [34] that argued that for social acceptance of wind energy, issues of logistics of transport and erection, medium-term sustainability of the political and economic support are critical. But in Ghana, there is a bleak funding opportunity for wind energy because the issue of wind energy is less prioritized.

Potential Challenges Associated with the Development of Wind Energy in Ghana 
Development of wind technology is without challenges. The study results emphasized major issues of inadequate funding and technology gap as key challenges impacting the development of wind energy in Ghana. Other less impacting challenges revolve around issues of the absence of appropriate policy to facilitate the use and implementation of wind energy. The outcome of the study also supports [33] who faulted issues of increasing share, energy storage, motivational conflicts, demand responses and optimal scheduling emerge as key factors limiting the smooth development of wind energy. Similarly, the study corroborates [34] that concluded that logistics of transport and erection, and issues of the medium-term sustainability of the political and economic support as major challenges to the development of wind energy.

Efforts to address such challenges ranked in order of applicability are the provision of financial support, appropriate technological aid, change in policy and education of the public on the importance of developing wind energy. The need to minimize the challenges to wind energy development should be a must if Ghana intends to address its energy shortfall through the development of alternative energy options such as wind energy.

\section{Conclusions}

The study investigated the differential impacts of wind energy to sustainable power generation in Ghana from the perspectives of the following;

- Assess the determinants of energy supply in Ghana.

- Examine energy demand and supply mix for energy development in Ghana.

- Explore the capacity of the energy sector to develop wind power energy in Ghana.

- Identify the possible challenges in developing wind power energy in Ghana.

Demand for energy in Ghana has increased over the years but without a commensurate increase in energy supply. Major reasons for the shortfall in energy supply have centred on the monopoly enjoyed by the major power producer which invariably places stress on its ability to supply energy to meet the increasing demand. Some arguments have centred on the need for diversity in energy sources including the need to explore opportunities in alternative sources of energy.

Although several alternative energy sources such as solar and natural gas have been introduced in Ghana, the supply of energy continues to lag behind the demand for energy. Wind energy has the potential to contribute to the overall energy fortunes of Ghana. However, a focus on wind energy may not produce the required results of reducing the energy supply gap due to a preference for solar and natural gas oils.

The need to build capacity to develop and maintain wind energy through critical, current infrastructure stance of the Ghanaian energy sector would not make this agenda of developing wind energy a reality. The need to enhance technology and relevant skills thereof are critical if the country intends to incorporate wind energy into the mainstream energy sources available to Ghana. The need to en- 
hance the current weak national policy, financial backing and bridge technology gap for wind energy would be needful to realise a vibrant investment into wind energy development.

\section{Acknowledgements}

The authors acknowledge the expert contributions of respondents from the Ministry of Energy to the manuscript.

\section{Conflicts of Interest}

The authors declare no conflicts of interest regarding the publication of this paper.

\section{References}

[1] Marwah, H. (2017) Electricity Access Inequality in Sub-Saharan Africa, 1950-2000. African Economic History, 45, 113-144. https://doi.org/10.1353/aeh.2017.0008

[2] Kebede, E., Kagochi, J. and Jolly, C.M. (2010) Energy Consumption and Economic Development in Sub-Sahara Africa. Energy Economics, 32, 532-537.

https://doi.org/10.1016/j.eneco.2010.02.003

[3] Ragheb, M. and Ragheb, A.M. (2011) Wind Turbines Theory-The Betz Equation and Optimal Rotor Tip Speed Ratio. In: Carriveau, R., Ed., Fundamental and Advanced Topics in Wind Power, IntechOpen Limited, London, 10-29. https://doi.org/10.5772/21398

[4] International Energy Agency (2014) Energy Security. International Energy Agency Energy Technology Systems Analysis Programme, Paris.

http://www.iea.org/topics/energysecurity/

[5] Nkrumah, F. (2002) Feasibility Study of Wind Energy Utilization along the Coast of Ghana. Unpublished MSc Project Report, Kwame Nkrumah University of Science \& Technology, Kumasi.

[6] Agbeve, M. S., Titiati, A. and Quaye, W. (2011) Emerging Technologies for Climate Change Adaptation: A Case Study in Dangbe East District of Ghana. African Technology Policy Studies Network, Nairobi.

[7] Awopone, A.K., Zobaa, A.F. and Banuenumah, B. (2017) Techno-Economic and Environmental Analysis of Power Generation Expansion Plan of Ghana. Energy Policy, 104, 13-22. https://doi.org/10.1016/j.enpol.2017.01.034

[8] Nelson, E., Mendoza, G., Regetz, J., Polasky, S., Tallis, H., Cameron, D., et al. (2009) Modeling Multiple Ecosystem Services, Biodiversity Conservation, Commodity Production, and Tradeoffs at Landscape Scales. Frontiers in Ecology and the Environment, 7, 4-11. https://doi.org/10.1890/080023

[9] Appiah, K.A. (2011) The Honor Code: How Moral Revolutions Happen. WW Norton \& Company, New York.

[10] Kumi, E.N. (2017) The Electricity Situation in Ghana: Challenges and Opportunities. Center for Global Development, Washington DC.

[11] Gloppen, K.M., Arthur, M.W., Hawkins, J.D. and Shapiro, V.B. (2012) Sustainability of the Communities That Care Prevention System by Coalitions Participating in the Community Youth Development Study. Journal of Adolescent Health, 51, 259-264. https://doi.org/10.1016/j.jadohealth.2011.12.018 
[12] Frondel, M., Ritter, N., Schmidt, C.M. and Vance, C. (2010) Economic Impacts from the Promotion of Renewable Energy Technologies: The German Experience. Energy Policy, 38, 4048-4056. https://doi.org/10.1016/j.enpol.2010.03.029

[13] Agbavor, D. (2015) Correlation between Sun Light Intensity and Wind Speeds of a Coastal Location. Vaasa University of Applied Sciences, Finland.

[14] Wolar, J. (2008) Meteorological Towers and Wind Power Analysis. General Primer. Revised in December 2008. Alternate Energy Solutions Inc., Toronto.

[15] Yihdego, Y., Salem, H.S. and Pudza, M.Y. (2017) Renewable Energy: Wind Farm Perspectives-The Case of Africa. Journal of Sustainable Energy Engineering, 5, 281-306. https://doi.org/10.7569/jsee.2017.629521

[16] Morris, M., Robbins, G., Hansen, U.E. and Nygaard, I. (2020) Energy and Industrial Policy Failure in the South African Wind Renewable Energy Global Value Chain: The Political Economy Dynamics Driving a Stuttering Localisation Process. University of Cape Town, South Africa.

[17] Ardo, S., Rivas, D.F., Modestino, M.A., Greiving, V.S., Abdi, F.F., Llado, E.A. Bederak, D., et al. (2018) Pathways to Electrochemical Solar-Hydrogen Technologies. Energy \& Environmental Science, 11, 2768-2783. https://doi.org/10.1039/C7EE03639F

[18] Smil, V. (2016) Energy Transitions: Global and National Perspectives. ABC-CLIO, Santa Barbara.

[19] Liner, C.L. and McGilvery, T.A. (2019) Historical Overview of Petroleum and Seismology. In: Liner, C.L. and McGilvery, T.A., Eds., The Art and Science of Seismic Interpretation, Springer, Cham, 41-56. https://doi.org/10.1007/978-3-030-03998-1_2

[20] Trencher, G., Rinscheid, A., Duygan, M., Truong, N. and Asuka, J. (2020) Revisiting Carbon Lock-In in Energy Systems: Explaining the Perpetuation of Coal Power in Japan. Energy Research \& Social Science, 69, Article ID: 101770. https://doi.org/10.1016/j.erss.2020.101770

[21] Didane, D.H., Ab Wahab, A., Shamsudin, S.S. and Rosly, N. (2016) Wind as a Sustainable Alternative Energy Source in Malaysia-A Review. ARPN Journal of Engineering and Applied Sciences, 11, 6442-6449.

[22] Arshad, M. and O’Kelly, B. (2019) Global Status of Wind Power Generation: Theory, Practice, and Challenges. International Journal of Green Energy, 16, 1073-1090. https://doi.org/10.1080/15435075.2019.1597369

[23] Calvert, K. and Simandan, D. (2010) Energy, Space, and Society: A Reassessment of the Changing Landscape of Energy Production, Distribution, and Use. Journal of Economics and Business Research, 16, 13-37.

[24] Zobaa, A.F. and Bansal, R.C. (2011) Handbook of Renewable Energy Technology. World Scientific Publishing, Singapore. https://doi.org/10.1142/7489

[25] Mastilović, S., Gburčik, P., Gburčik, V., Gavrilov, M. and Srdanović, V. (2006) Complementary Regimes of Solar and Wind Energy in Serbia. Geographica Pannonica, 10, 22-25. https://doi.org/10.5937/GeoPan0610022G

[26] Wang, L.F. and Singh, C. (2009) Multicriteria Design of Hybrid Power Generation Systems Based on a Modified Particle Swarm Optimization Algorithm. IEEE Transactions on Energy Conversion, 24, 163-172. https://doi.org/10.1109/TEC.2008.2005280

[27] Zhang, S.F. and He, Y.X. (2013) Analysis on the Development and Policy of Solar PV. Power in China. Renewable and Sustainable Energy Reviews, 21, 393-401. 
https://doi.org/10.1016/j.rser.2013.01.002

[28] Sovacool, B.K. and Watts, C. (2009) Going Completely Renewable: Is It Possible (Let Alone Desirable)? The Electricity Journal, 22, 95-111.

https://doi.org/10.1016/j.tej.2009.03.011

[29] Pierce, W., Gauché, P., von Backström, T., Brent, A.C. and Tadros, A. (2013) A Comparison of Solar Aided Power Generation (SAPG) and Stand-Alone Concentrating Solar Power (CSP): A South African Case Study. Applied Thermal Engineering, 61, 657-662. https://doi.org/10.1016/j.applthermaleng.2013.08.014

[30] Zhao, X.L., Zhang, S.F., Zou, Y.S. and Yao, J. (2013) To What Extent Does Wind Power Deployment Affect Vested Interests? A Case Study of the Northeast China Grid. Energy Policy, 63, 814-822. https://doi.org/10.1016/j.enpol.2013.08.092

[31] Tong, C.W., Zainon, M.Z., Chew, P.S., Kui, S.C., Keong, W.S. and Chen, P.K., (2010) Innovative Power-Augmentation-Guide-Vane Design of Wind-Solar Hybrid Renewable Energy Harvester for Urban High Rise Application. AIP Conference Proceedings, 1225, 507-521. https://doi.org/10.1063/1.3464898

[32] Cochrane, P. (2006) Exploring Cultural Capital and Its Importance in Sustainable Development. Ecological Economics, 57, 318-330.

https://doi.org/10.1016/j.ecolecon.2005.04.012

[33] Xu, J.P. and Liu, T.T. (2020) Technological Paradigm-Based Approaches Towards Challenges and Policy Shifts for Sustainable Wind Energy Development. Energy Policy, 142, Article ID: 111538. https://doi.org/10.1016/j.enpol.2020.111538

[34] McKenna, R., Leye, P.O. and Fichtner, W. (2016) Key Challenges and Prospects for Large Wind Turbines. Renewable and Sustainable Energy Reviews, 53, 1212-1221. https://doi.org/10.1016/j.rser.2015.09.080

[35] Global Wind Energy Council (2011) Global Wind Report-Annual Market Update. Global Wind Energy Council, Brussels.

[36] Arshad, M. and O’Kelly, B.C. (2016) Analysis and Design of Monopile Foundations for Offshore Wind-Turbine Structures. Marine Georesources \& Geotechnology, 34, 503-525. https://doi.org/10.1080/1064119X.2015.1033070

[37] Baagøe-Engels, V. and Stentoft, J. (2016) Operations and Maintenance Issues in the Offshore Wind Energy Sector. International Journal of Energy Sector Management, 10, 245-265. https://doi.org/10.1108/IJESM-04-2015-0012

[38] Kilduff, M. and Tsai, W. (2003) Social Networks and Organizations. SAGE Publications Ltd., Thousand Oaks, CA. https://dx.doi.org/10.4135/9781849209915

[39] Krejcie, R.V. and Morgan, D.W. (1970) Determining Sample Size for Research Activities. Educational and Psychological Measurement, 30, 607-610.

https://doi.org/10.1177/001316447003000308

[40] Saunders, M.N. and Lewis, P. (2012) Doing Research in Business \& Management: An Essential Guide to Planning Your Project. Pearson Education, Canada.

[41] Robson, C. and McCartsn, K. (2011) Real World Research. John Wiley \& Sons Ltd., West Sussex.

[42] Ahadzie, D.K., Proverbs, D.G. and Olomolaiye, P.O. (2008) Model for Predicting the Performance of Project Managers at the Construction Phase of Mass House Building Projects. Journal of Construction Engineering and Management, 134, 618-629. https://doi.org/10.1061/(ASCE)0733-9364(2008)134:8(618)

[43] Mead, I. (2017) International Energy Outlook 2017. U.S. Energy Information Administration, USA. https://doi.org/10.1016/j.rser.2012.11.047

[44] Mohammed, Y.S., Mokhtar, A.S., Bashir, N. and Saidur, R. (2013) An Overview of 
Agricultural Biomass for Decentralized Rural Energy in Ghana. Renewable and Sustainable Energy Reviews, 20, 15-25. https://doi.org/10.1016/j.rser.2012.11.047

[45] Mensah, G.S., Kemausuor, F. and Brew-Hammond, A. (2014) Energy Access Indicators and Trends in Ghana. Renewable and Sustainable Energy Reviews, 30, 317-323. https://doi.org/10.1016/j.rser.2013.10.032 